\title{
Improving Students' Problem-Solving Skills Using Inquiry Learning Model Combined with Advance Organizer
}

\section{Gunawan Gunawan}

Dr., Universitas Mataram, Indonesia, gunawan@unram.ac.id

\author{
Ahmad Harjono \\ Dr., Universitas Mataram, Indonesia, harjonofkip@unram.ac.id \\ Mir'atun Nisyah \\ Universitas Mataram, Indonesia, miratunnissaa99@gmail.com

\section{Mahesti Kusdiastuti} \\ Universitas Mataram, Indonesia, mahestikusdiastuti25@gmail.com

\section{Lovy Herayanti} \\ Dr., IKIP Mataram, Indonesia, lovyherayanti@ikipmataram.ac.id
}

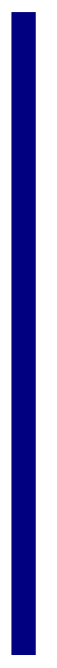

This research has developed learning tools of inquiry models combined with advance organizers in order to activate students' initial knowledge and improve their problem-solving skills. This article focuses on delivering the trial phase of the development process. The trial phase used non-equivalent pre-test post-test control group design to determine the effectiveness the combination of inquiry learning models and advance organizer approach. The population involved high school students in Mataram city and sampling was done by using cluster random sampling technique. Two groups were chosen and divided into experimental and control classes. The instrument used in the study is problem solving essay test consisting of 5 questions. Data were analysed using the Mann-Whitney test at a 5\% level of significance, followed by the effect size and $\mathrm{N}$-gain to find out the level of students' problem-solving skills improvement. Based on the result, it was found that the students in the experimental class who used a combination of inquiry learning models and advance organizer had significantly problem-solving skills' improvement than the control class that only used inquiry learning models. Also. the experimental group had a higher ability to focus on the problems, make a plan and implement it to find the solutions.

Keywords: advance organizer, inquiry model, problem-solving skills, learning model, problem-solving

Citation: Gunawan, G., Harjono, A., Nisyah, M., Kusdiastuti, M., \& Herayanti, L. (2020). Improving Students' Problem-Solving Skills Using Inquiry Learning Model Combined with Advance Organizer. International Journal of Instruction, 13(4), 427-442. https://doi.org/10.29333/iji.2020.13427a 


\section{INTRODUCTION}

The ability to solve problems is one of the basic skills everyone needs in order to face the increase demands in a complex life. Generally, problem-solving skills development is one of the focuses on the 21st-century educational goals (Gongden, 2016; Kivunja, 2015; Wang, et al., 2018), especially in physics education (Shishigu et al., 2018; Taasoobshirazi \& Farley, 2013). Apart from understanding concepts (Docktor et al., 2016; Yuliati et al., 2018), physics aim at improving the problem-solving skills of individuals (Harjono, 2012; Soetopo, 2016). Problem-solving is a cognitive process of finding means to achieve goals (Mefoh et al., 2017; OECD, 2014) which depends on the ability to compile and process information (Sujarwanto \& Hidayat, 2014). The stages involved in addressing problems are often covered in physics education (Gunawan et al., 2015).

Scientific literacy has been introduced to the students since in elementary school (Raizen \& Michelsohn, 1994) as a part of science class - the combination of physics, chemistry and biology. In Indonesia, the students start to learn physics at the secondary school level. It aims to help the students in mastering the concept and developing the skills or ability to investigate, collaborate, think and solve problems (Jufri, 2017).

Problem-solving is a generic aptitude which includes the ability to understand issues as well as the stages involved (Mandina et al., 2018). Generally, there are five stages, including focusing the problems, describing it into physics concepts, planning the solutions, implementing the plans, and evaluating the solutions (Docktor et al., 2016). The process involves understanding the problem, choosing the proper concept and checking the problem suitability with the proposed solution. It requires a good understanding of concepts and high-level thinking skills (Hermansyah et al., 2019; Yuliati et al., 2018).

The application of the right learning model has a positive influence on achieving goals and training students' problem-solving skills (Biljana \& Dragana, 2017; Naz \& Murad, 2017). Problem-solving skills training is often made by integrating stages of solving physical problems in syntax or learning activities (Gunawan et al., 2015). In the PISA 2015, Indonesia was in the $115^{\text {th }}$ position out of 124 participating countries (Hadi et al., 2018. Indonesian students could only perform first four levels, while they still had difficulties in the last two levels (OECD, 2016). The results of these studies have provided information that students' high order thinking skills involving problem solving skills in Indonesia is still low). This is reinforced by several studies on the profile of students' in physics problem-solving skills (Datur et al., 2016; Jua et al., 2018; Susiana et al., 2017). The activities involved activities are facilitated during the learning process with models, methods, media and proper teaching materials (Gunawan et al., 2018; Susiana et al., 2017).

One of the suitable learning models that suitable for facilitating the problem-solving stages is inquiry since all of the five problem-solving stages are integrated in its syntax (Mandina et al., 2018). The inquiry is a learning model which provides students with 
relevant experience, helping them to apply scientific methods, train and develop relevant skills (Arslan, 2014; Berlman, 2003; Gunawan et al., 2019; Pedaste et al., 2015).

The inquiry learning model is a series of activities which boost the students' opportunities to construct their own knowledge and develop problem-solving skills. It is reflected from the steps of inquiry as follows. The first step is orientation, the process of stimulating the students' curiosity on a topic through a problem statement. Continued by the second step, conceptualization, the process of expressing questions based on theory and/or hypothesis. The third step is investigation, the process of planning, collecting and analyzing data from exploration or experimentation. It followed by the fourth step, conclusion, the process of making deductions. The last step is discussion, the process of presenting the results of an investigation (Pedaste et al., 2015).

Even though some previous studies for instance Prahani (2016) \& Primadani (2017) showed that inquiry models had an effect on improving students' physics solving skills, Bunterm et al. (2012) found differently. It was stated that there were no significant differences in problem-solving skills between classes taught with models of inquiry and the conventional classes. This is attributed to a number of factors, including 1) students are not accustomed to learning and thinking independently, and 2) not all students are ready to carry out inquiry activities directly (Andrini, 2016; Arslan, 2014; Artayasa et al., 2018).

Reflected to the case of Bunterm et al. (2012), it is necessary to consider the mental condition and cognitive structure of the students in the inquiry learning model. Cognitive Structure is one of the main factors used to determine the mindfulness of new knowledge and how well it might be maintained in students' memory (Ausubel, 1968). Meaningful learning occurs where the knowledge taught has a relationship or has been stored in the cognitive structure of students (Hamdanillah et al., 2017; Harjono et al., 2018). Besides, the knowledge obtained in inquiry activities must be stored or connected to the cognitive structure of students, and this is possibly carried out by activating students' prior understanding. A good prior knowledge help in compiling information and finding the right solution (Sujarwanto \& Hidayat, 2016).

The requirement in cognitive structure can be supported by the implementation of advance organizer. By using advance organizer principal, a small amount of verbal, visual graphic or written information is presented to learners in advance of new material that is to be learned within an instructional session (Githua \& Rachel, 2008). Therefore, advance organizer will give students a focus in every process of instruction and motivate all students to participate in all the activities they need to build their mental state and cognitive structure.

The advance organizer approach is often used to prepare and strengthen students' cognitive structures (Joyce et al., 2013). It was developed based on Ausubel theory of Meaningful Learning. Basically, meaningful learning works perfectly with an understanding that occurs when the new information has a connection with existing concepts stored in cognitive structures (Ausubel, 1968; Hamdanillah et al., 2017; Harjono et al., 2018). The advance organizer approach consists of three phases; 1) 
advanced organizer presentation; 2) presentation of learning assignments or material, and 3) strengthening cognitive structures through the principle of integrative reconciliation (Joyce et al., 2013).

Evidently, advance organizer is strongly suitable to be integrated with inquiry model. The basis combination of inquiry and advanced organizer learning models is adapted from Pedaste et al. (2015) and Joyce et al. (2013). The phase of inquiry learning model is aimed to improve the students' problem-solving skills while the support from advanced organizer is meant to enable and strengthen the cognitive structure of students (Saputra et al., 2019), improve learning outcomes (Lott, 1983) and enhance students' motivation (Shihusa \& Kerato, 2009) for a better constructed mental.

Previously, advance organizer was combined with 5E model and it was able to improve the learning outcomes (Korur et, al 2016). Consider the success of the former research, the present study combined inquiry and advanced organizer in order to boost students' problem-solving skills. The purpose of the study was to describe the effectiveness of the inquiry model combined with advanced organizer in improving students' problemsolving skills. Inquiry learning model combined with advance organizer proved to be effective toward problem solving skills if there were significant differences between students' pre-test and post-test and also there was an increase in scores indicated by the n-gain test.

\section{METHOD}

\section{Research design}

This research is a development research consisting of three stages: product design and development (including product validation), product trials (large and small scale) and product dissemination. This article discussed the result of product trial stage.

During the trial stage, the product was implemented in the real classroom by using nonequivalent pre-test post-test control group design (Creswell, 2012). To examine the effectivity, two groups were chosen. One group is called the experimental group who were taught using the inquiry learning model combined with advance organizer. The second group is called the control group who were taught using the inquiry learning model only. The research matrix is shown in Table 1.

Table 1

Research Matrix

\begin{tabular}{llll}
\hline Groups & Pre-Test & Experiment & Post-Test \\
\hline Experimental & $\mathrm{X}$ & Inquiry Learning Models + Advance Organizer` & $\mathrm{X}$ \\
\hline Control & $\mathrm{X}$ & Inquiry Learning Models & $\mathrm{X}$ \\
\hline
\end{tabular}

The combination of inquiry learning model and advance organizer is contained in a combination of both syntaxes, into a single unit that is complementary to each other. The syntax of inquiry learning models combined with advanced organizer is shown in Table 2 . 
Table 2

Syntax of Inquiry Learning Model with Advance Organizer (AO)

\begin{tabular}{|c|c|c|}
\hline Inquiry Model & AO Model & Inquiry combined with $\mathrm{AO}$ \\
\hline Orientation Phase & AO Presentation Phase & AO Presentation Phase \\
\hline \multirow{4}{*}{$\begin{array}{l}\text { Stimulate student } \\
\text { curiosity about a topic } \\
\text { through a problem } \\
\text { statement }\end{array}$} & \multirow{4}{*}{$\begin{array}{l}\text { The teacher explains the purpose } \\
\text { of the lesson, presents the AO, } \\
\text { and draws the attention of } \\
\text { students with relevant knowledge }\end{array}$} & The teacher explains the purpose of the \\
\hline & & lesson, presenting/giving $\mathrm{AO}$ \\
\hline & & Orientation Phase \\
\hline & & $\begin{array}{l}\text { The teacher stimulates curiosity about a } \\
\text { topic through a problem statement }\end{array}$ \\
\hline Conceptualization Phase & Learning Task Presentation Phase & Conceptualization Phase \\
\hline $\begin{array}{l}\text { Students in groups } \\
\text { formulate problems and } \\
\text { hypotheses }\end{array}$ & $\begin{array}{l}\text { The teacher presents assignments } \\
\text { or learning the material and } \\
\text { makes the organization and } \\
\text { logical sequence of learning } \\
\text { material explicit }\end{array}$ & $\begin{array}{l}\text { Students in groups formulate problems } \\
\text { and hypotheses }\end{array}$ \\
\hline Investigation Phase & Cognitive Structure Strengthening & Investigation Phase \\
\hline Students in groups design & Phase & Students in groups design exploration or \\
\hline $\begin{array}{l}\text { exploration or } \\
\text { experiment, collect and } \\
\text { analyze data }\end{array}$ & $\begin{array}{l}\text { Teachers and students carry out } \\
\text { an integrative adjustment process } \\
\text { and acceptance of active learning, } \\
\text { obtaining a critical approach to } \\
\text { learning material. } \\
\text { (Joyce et al., 2013) }\end{array}$ & ollect and analyze data \\
\hline Conclusion Phase & & Conclusion Phase \\
\hline $\begin{array}{l}\text { Students draw } \\
\text { conclusions from the data }\end{array}$ & & Students draw conclusions from the data \\
\hline Discussion Phase & & Discussion Phase \\
\hline Students present the & & Students present the findings \\
\hline findings & & The phase of Integrative Reconciliation \\
\hline (Pedaste et al., 2015) & & $\begin{array}{l}\text { Teachers and students make an } \\
\text { integrative adjustment process to the } \\
\text { subject matter. }\end{array}$ \\
\hline
\end{tabular}

Implementation of the inquiry model combined with advanced organizer was carried out in three meetings. Each meeting consisted of two hours of study each for 45 minutes. Hence, the total time for treatment was 270 hours. The distribution of materials in each meeting can be seen in the following Table 3 .

Table 3

Student Activities during the Implementation of the Inquiry Model with Advance Organizer

\begin{tabular}{lll}
\hline Meetings & Learning materials & Learning Objectives \\
\hline \multirow{2}{*}{ First } & Work and Energy Concepts & $\begin{array}{l}\text { Students distinguish work by force in the same } \\
\text { direction and form angles with displacement }\end{array}$ \\
\cline { 2 - 3 } & Kinetic Energy & $\begin{array}{l}\text { Students analyze relationships of work with } \\
\text { kinetic energy }\end{array}$ \\
\hline \multirow{2}{*}{ Second } & Potential Energy & Students analyze potential energy equations \\
\cline { 2 - 3 } Third & $\begin{array}{l}\text { Conservative and Non- } \\
\text { Conservative Forces }\end{array}$ & $\begin{array}{l}\text { Students distinguish business by conservative and } \\
\text { non-conservative forces }\end{array}$ \\
\hline & $\begin{array}{l}\text { Mechanical Energy } \\
\text { Conservation Law }\end{array}$ & $\begin{array}{l}\text { Students solve problems in everyday life related } \\
\text { to the conservation of mechanical energy laws }\end{array}$ \\
\hline
\end{tabular}




\section{Population and Samples}

This research was conducted at a high school in the city of Mataram, West Nusa Tenggara Province, Indonesia. The population was the students in class X consist of 200 students both in the mathematics and science program in the second semester of academic 2018/2019. The sample was determined by using cluster random sampling techniques. From the process, two classes were selected. One group is assigned as experimental group consist of 22 students and the other one as control group consist of 25 students.

\section{Data Collection and Analysis Techniques}

The study employed a written test form with 5 questions related to Work and Energy topic which were developed based on indicators of problem-solving skills. To ensure the validity of the test, expert validation, construct validation and content validation were performed. The results indicated that problem solving test instrument was in the valid criteria and obtained 5 valid problem solving questions.

The problems were formulated using daily life context. For instance, the problem in finding a solution if you want to move an object with greater mass with smaller effort or a solution if you want to move objects in an inclined plane. Students are guided to understand the problems, make a plan, carry it out, and evaluate the solution. All of these processes are based on the syntax of inquiry learning model. The advance organizers principals were used as scaffolding to help the students in each process to make learning easier and more effective.

Problem-solving skills was assessed based on scoring at intervals of 0-4 in accordance with the rubric and the stages adapted from Docktor et al. (2016) and Heller et al. (1992). Data were then statistically analyzed using SPPS 21.0. to obtain the results of the pretest-posttest descriptive analysis, to find out whether or not there is a difference between pre-test and post-test, the Mann Whitney test analysis is employed due to pre test and post-test data are not normally distributed and the enhancement of students' problem-solving skill was determined by normalized gain (N-gain) scores (Hake, 1999).

$$
N-\operatorname{gain}=\frac{\left(S_{p o s t}-S_{p r \theta}\right)}{\left(S_{\text {max }}-S_{p r \theta}\right)}
$$

The improvement is considered as high if $\mathrm{N}$-gain $>0.70$, medium if $0.30 \leq \mathrm{N}$-gain $\leq$ 0.70 and low if $\mathrm{N}$-gain $<0.30$.

To examine the mean differences between the two groups The Mann Whitney test was carried out. To support the result, the effect size test with the Cohens test using the Size Calculator was also employed. 


\section{FINDINGS}

\section{Pretest and Posttest Scores of Problem-Solving Skills}

The scores of the pretest and posttest problem-solving skills of the experimental and control groups were analyzed descriptively and presented in Table 4.

Table 4

Results of Descriptive Analysis Pretest and Posttest Scores

\begin{tabular}{|c|c|c|c|c|c|c|c|c|}
\hline \multirow[t]{2}{*}{ Test } & \multicolumn{3}{|c|}{$\begin{array}{l}\text { Experimental Group } \\
(\mathrm{N}=22)\end{array}$} & \multirow[t]{2}{*}{ Std } & \multicolumn{3}{|c|}{$\begin{array}{l}\text { Control Group } \\
(\mathrm{N}=25)\end{array}$} & \multirow[t]{2}{*}{ Std } \\
\hline & Min & Max & Average & & Min & Max & Average & \\
\hline Pretest & 2.00 & 25.00 & 12.00 & 5.84 & 4.00 & 26.00 & 11.24 & 4.35 \\
\hline Posttest & 50.00 & 92.00 & 70.38 & 11.32 & 18.00 & 67.00 & 39.72 & 10.62 \\
\hline
\end{tabular}

From Table 3, the average scores of the pretest of the experimental group was 12.00 while the control group was 11.24. Based on the homogeneity test of the initial problemsolving skills of the two classes using the Mann-Whitney Test, a significance scores of 0.541 was obtained. The coefficient obtained was greater than 0.05 so it can be used as a reference that the experimental class and the control class do not differ significantly in their initial problem-solving skills. Whereas, the average posttest scores between the experimental and control classes showed a considerable difference, where the average posttest scores of the experimental group was 70.38 and 39.72 for the control group.

\section{Results of Pretest Scores and Posttest Analysis of Problem-Solving Skills}

The pretest and posttest scores were calculated to determine the level of improvement in students' problem-solving skills after the implementation of the inquiry model combined with advanced organizer. The results of the recapitulation analysis of the average $\mathrm{N}$ Gain score on the problem-solving skills test are presented in Table 5.

Table 5

N-Gain Scores on Pretest and Posttest Scores of Problem-Solving Skills

\begin{tabular}{lllll}
\hline Group & $\begin{array}{l}\text { Average Pretest } \\
\text { Scores }\end{array}$ & $\begin{array}{l}\text { Average Posttest } \\
\text { Scores }\end{array}$ & $\begin{array}{l}\text { Average Gain } \\
\text { Score }\end{array}$ & Category \\
\hline Experimental & 11.95 & 69.05 & 0.66 & Medium \\
\hline Control & 10.61 & 39.74 & 0.37 & Medium \\
\hline
\end{tabular}

According to Hake's interpretation (1999), both groups were in medium category in term of improvement in problem solving skills. However, the average gain scores of the experimental group were higher than the control group. Furthermore, we examined the $\mathrm{N}$-gain score for each problem-solving stage. The results can be observed in Table 6 . 
Table 6

N-Gain Scores on Pretest and Posttest Scores in Each Stage of Problem-Solving

\begin{tabular}{llllll}
\hline $\begin{array}{l}\text { Stages of Problem } \\
\text { Solving }\end{array}$ & Group & $\begin{array}{l}\text { Pretest Average } \\
\text { Scores }\end{array}$ & $\begin{array}{l}\text { Posttest } \\
\text { Average Scores }\end{array}$ & $\begin{array}{l}\text { Average Gain } \\
\text { Score }\end{array}$ & Category \\
\hline \multirow{2}{*}{$\begin{array}{l}\text { Focus the Problem } \\
\text { Describe the Problem } \\
\text { into Physics Concepts }\end{array}$} & Experiment & 45.00 & 92.5 & 0.86 & High \\
\cline { 2 - 6 } & Control & 32.61 & 66.52 & 0.50 & Medium \\
\cline { 2 - 6 } Plan the Solution & Control & 0.00 & 34.5 & 0.34 & Medium \\
\hline & Experiment & 3.50 & 2.17 & 0.02 & Low \\
\cline { 2 - 6 } Implement the Plan & Control & 9.35 & 87.00 & 0.87 & High \\
\cline { 2 - 6 } & Experiment & 5.00 & 58.48 & 0.77 & Hedium \\
\hline $\begin{array}{l}\text { Evaluate the } \\
\text { Solutions }\end{array}$ & Control & 8,04 & 78.00 & 0.55 & Medium \\
\hline
\end{tabular}

From Table 6, the average $\mathrm{N}$-gain score of the experimental group is categorized as medium-high while the control group is low-medium. For each stage, the students in experimental group also performed better than control group.

\section{Results of Mann-Whitney Test Analysis}

The hypothesis was tested using Mann-Whitney test in SPSS 21. The results are shown in Table 7.

Table 7

Result of Hypothesis Test

\begin{tabular}{lll}
\hline Mann-Whitney Test & Sig. Value & Interpretation \\
\hline Posttest & .000 & $\begin{array}{l}\text { There are differences in problem-solving skills between } \\
\text { the two groups }\end{array}$ \\
\hline N-Gain Posttest & .000 & $\begin{array}{l}\text { There are differences in N-gain scores for problem- } \\
\text { solving skills between the two groups }\end{array}$ \\
\hline
\end{tabular}

From the Table 7, the initial skills of the two groups were not significantly different. However, the results of the posttest and the N-Gain score of the problem-solving skills of the two groups differed significantly. From these results, the inquiry model combined with advanced organizer influences students' problem-solving skills.

\section{Result of Analysis of Effect Size Test}

The effect size analysis results using Cohen's test with the R-stat Effect Size Calculator on the $\mathrm{N}$-gain score as shown in Table 8.

Table 8

Result of Analysis of Effect Size Test

\begin{tabular}{lllll}
\hline Group & Average & Std & Cohen's d & Interpretation \\
\hline Experimental & 0.66 & 0.12 & 2.416 & Large \\
\hline Control & 0.32 & 0.12 & & \\
\hline
\end{tabular}

\section{DISCUSSION}

Based on the Mann-Whitney test, the combination of Inquiry and Advance Organizer in work and energy topic is effectively improve the students' physical problem-solving 
skills. Also, the outcome of the size effect test proved how much the treatment impact the developed skills (Yuliani et al., 2018).

The results of this study are in line with previous studies which stated that the combination of learning models improve students' high-level thinking skills (Mashami \& Gunawan, 2018; Saputra et al., 2019). Additionally, it has a positive impact on students' problem-solving skills in physics (Amanah et al., 2017). Guided inquiry model in learning physics can help students become more creative, especially in aspects of procedural and figural creativity (Wahyuni et al., 2019).

The gained result is likely to happen since the combined learning situation with Inquiry and Advance Organizer is developed based on constructivism and meaningful learning principals (Pedaste et al., 2015; Hamdanillah et al., 2017). The model consisted of the stages of problem-solving through problem presentations \& orientation, conceptualization, investigation, conclusions, discussion, and integrative reconciliation (Pedaste et al., 2015; Joyce et al., 2013). Problem-solving skills are trained through the process of organizing information and determining the relevant approach to finding solutions to issues in inquiry learning. The learning process involves applying the inquiry model combined with effective advance organizer to train students. Integration of stages of problem-solving in effective learning syntax enhances students' skills in this regard (Shishigu et al., 2017).

Presentation stage is effectively helping the students to understand the conceptual framework and activities during inquiry learning. Generally, the inquiry activities require a good initial knowledge of students and facilitate learners with poor initial knowledge. This step provides a meaningful scaffolding for inquiry learning (Thacker \& Friedman, 2017). For this reason, the type of presentation needs to be adjusted to the information delivered to students (Ni et al., 2016).

Work and energy are materials composed of concepts and their relationships. Therefore, researchers chose advance organizer in graphic organizers in the form of a concept map. The researcher made three concept maps used for three meetings. Concept maps are intended to provide information to students about ideas and the existing relationships between them from the material comprehensively. The concepts are presented hierarchically starting with the most common ones at the top then proceeding with the more specific at the bottom. This is supported by Ausubel argument that the information obtained is meaningful if arranged according to the process and cognitive structure of students (Ausubel, 1968; Iofciu et al., 2011). The use of appropriate concept maps in advance organizer presentations helps students understand the concepts used to solve problems in inquiry activities. This is in line with Amanah et al. (2016) which states that the advance organizer concept map integrated into the learning model has a positive impact on improving students' problem-solving skills in physics.

Orientation step of the combined model is effective in training problem-solving skills at the focus the problem stage. This is the stage where students are required to recognize information, translate problems into visual representations, and identify proper approaches (Heller et al., 1992; Doctor et al., 2016). In this syntax, the teacher gives a 
stimulus in the form of problems and questions which make students guess possible answers to problems based on the initial knowledge and presentation of the advance organizer. The stimulus that is proper or relevant to student knowledge encourages the curiosity and enthusiasm to learn (Artaysa et al., 2018). The effectiveness of the inquiry model syntax combined with advance organizer in improving problem-solving skills is indicated by the $\mathrm{N}$-gain score of 0.66 , hence categorized as high.

Conceptualization step of the model is effective in training students at the stage of describing the problem into physics concepts. The phase involves determining the physical representation of the problem (Heller et al., 1992). Students are expected to identify problems from the previous syntax, then they make a number of questions are appropriate to the problem or phenomenon presented. This facilitates students to think and connect relevant concepts in order to make scientific questions and hypotheses (Artayasa, et al., 2018).

Investigation step of inquiry of the combined model in work and energy material is effective in helping students develop relevant problem-solving skills. In this syntax, students do an experiment or exploration plan, collect and analyze data (Pedaste et al., 2015). Before carrying out an experiment or exploration, they formulate work steps in order to obtain relevant data to answer questions or problems in the worksheet. Experimental or exploratory activities improve students' science process skills and develop the ability to plan, work based on relevant data and information (Ogan \& Arslan, 2014; Kostelnikova \& Ozvoldova, 2013). Problem-solving skills at the stage of planning solutions and implementing plans involve activities in the investigative syntax.

Conclusions step in work and energy material. Here students are expected to draw conclusions from the data obtained and compare with the hypothesis or the problem presented. This syntax effectively trains students' problem-solving skills at the stage of evaluating solutions. Evaluating is the ability to provide explanations, make judgments based on data or evidence (Anderson \& Krathwohl, 2001).

Discussion step of the inquiry model is also very effective. Students in this syntax discuss information obtained in the previous activity then apply the stages of problemsolving into the sample text. The discussion involves the ability to understand, apply, analyze and evaluate, and the syntax applies to all stages of problem-solving simultaneously.

The step of strengthening the cognitive structure of students is the last phase in is carried out based on the principle of integrative reconciliation and it is intended to unite and store concepts into the cognitive structure of students (Ausubel, 1968, Hamdanillah et al., 2017; Harjono et al., 2018). On the basis of facilitating integrative reconciliation of new concepts into the cognitive structure of students, teachers should be; 1) reminding students the purpose of learning, 2) asking learners to summarize the concepts of the materials used, and 3) repeating definitions appropriately (Joyce et al., 2013). The integrative reconciliation activity influences the process of uniting and storing information in students 'memory, making the understanding of the concept more comprehensive. 
Mastery of problem-solving skills is determined by several important indicators. There are five indicators of problem-solving skills that researchers measured in this study. The first indicator is focus to the problem. This indicator is an indicator that has increased quite high among other indicators of problem-solving skills. The N-Gain score obtained by the students of the experimental class in this indicator reached 0.86 with a high category of improvement, while students in the control class only gained an increase of 0.50 with the medium category. It can be understood that the combination of inquiry learning models and advance organizer approaches is proven to be able to increase student focus on the problems given to them.

At the beginning of the meeting students have difficulty understanding the problems given to them due to lack of motivation and a good cognitive basis. The existence of the application of an advanced organizer really helps students to increase motivation in understanding and deepening the problems given. As a study conducted by Alfin et al. (2019) which shows a positive relationship between increasing problem-solving skills with students' confidence and motivation in learning.

Increased motivation is largely affected by the the use of advance organizers in helping students to focus on the problems given and the concepts that accompany them. This is because the advance organizer helps students manage themselves and ultimately increases their motivation (McManus, 2010; Shihusa \& Keraro, 2009). The use of presentations as a first step in the advance organizer helps students understand the concept map being studied and helps students build the basic knowledge, they will use in finding solutions to the problems given. Unlike the control class which only applies the inquiry learning model without the help of an advance organizer, the increase in focus on the problem is only in the moderate category. This is because student motivation does not increase as much as increased motivation in the experimental class.

The second indicator is describing the problem. When a student focus on the problem, they will easily describe it. Description of the problem is needed as a tool to simplify the problem and pour it into the description sentence so that it is easier to understand. In the experimental class the students' ability to describe the problem given was 0.34 in the medium category while in the control class there was almost no significant improvement (the increase was only 0.02 in the low category). It can be understood that the role of advance organizer is very visible in terms of giving students focus to the problem (indicator 1). If students are more focused, more motivated and have a better basic concept, then of course they can better describe the problem at hand and relate it to the correct concepts of physics.

The third indicator is planning solutions. The same thing happened to this third indicator a fairly high increase experienced by experimental class students in the ability to plan solutions to the problems encountered. Noted the experimental group got an increase score of 0.87 with a high increase category while the control group only got an increase score of 0.54 in the medium category. Indicator 3 is also strongly influenced by indicators 1 and 2, if students have focused and understood the given problem, then are able to relate it to the correct concept then of course they will more easily make a solution plan. The combination of inquiry learning model and advance organizer is 
better in supporting students to build indicators 1 and 2, the role of advance organizer in improving motivation and basic concepts is really able to boost students' ability in planning solutions.

The fourth indicator is the implementation of the plan. As with the previous four indicators, students' ability to carry out plans to find solutions to a given problem. Students in the experimental class got an increase score of 0.77 in the height increase category and students in the control class only got an increase score of 0.55 in the medium category. Students in the experimental class are better at organizing the discussion in each group during the plan execution process. Better motivation and better concept map knowledge really help students in working to find solutions. In the control class, although there was an increase, but it was not as big as the increase in the experimental group, because the inquiry learning model of the advance organizer sign caused students to be less effective in discussions, causing learning not to be as effective as the experimental class.

The last indicator is the evaluation of solutions. At the last stage students are asked to evaluate the solutions they propose. Very visible differences in the ability of students in the experimental class and control class in evaluating the solutions they provide. The experimental class was able to increase their evaluation skills by 0.51 in the medium category while the control class was only able to increase by 0.10 in the low category. In the combination of inquiry learning and advance organizer there is an integrative reconciliation that helps students evaluate the solutions they propose. In the control class only limited discussion so that from the beginning students have capital (understanding of concepts) that are less stable then the discussion between students will not increase understanding or even be able to determine the truth of the solutions they propose. This is supported by research by Sari et al. (2019) who found that learning that improves problem solving skills in students is learning that is able to activate communication among students to students and students to teachers. The quality of a good ability to evaluate a solution and connect it with the correct concepts, also requires other higherorder thinking skills, such as critical thinking skills. The more critical a student, the better the ability to evaluate. According to Gunawan et al (2019). the combination of inquiry learning models and advance organizer approaches is able to improve students' critical thinking skills.

The improvement of the five indicators in the experimental class that is higher than the control class proved that the inquiry learning model is more effective if it is combined with Advance Organizer approach. This is because, the increase on students' motivation and initial understanding on the topic that happened due to the support of Advance Organizer which gives interesting concept maps, presentations, orientations and reconciliation before, during and after finding the solutions. The control class that only uses inquiry learning also experiences improvement in students' problem-solving indicators, but students' motivation was not as good as in the experimental class. It makes the students in the experimental class have better problem-solving skills.

The effectiveness of the Inquiry and Advance Organizer in enhancing stages of problemsolving skills is also supported by the role of the teacher in assisting and supervising 
students in the learning process. The character, psychology, students' academic skills, and learning environment factors also influence the effectiveness of the approaches used (Budsankom et al., 2015). For this reason, teachers need to effectively arranging the classes, knowing and understanding the character of students and boosting their mastery of content.

Problem-solving ability is one of the high-level thinking skills requiring the ability to understand, apply, analyze, and evaluate. An individual with the skills or skills of thinking and problem solving might be successful in the personal and community life (Gagne, 1980). Basically, problem-solving skills help students face the challenges of the 21 st century, in particular, the increasingly complex life developments and changes (Kivunja, 2015).

\section{CONCLUSION}

It can be concluded that the inquiry model combined with advance organizer applied to work and energy material improve students' problem-solving skills. The effectiveness of this approach is evident in the Mann-Whiney test which shows there is an influence in improving students' problem-solving skills. The results of the $\mathrm{N}$-gain average score in the experimental group were higher than the control group in the medium category. The $\mathrm{N}$-gain score for each stage of problem-solving is categorized as high at the stage of focusing the problem, planning the solution and implementing the plan. However, the stage of describing the problem into the concept and evaluating it is categorized medium. Every stage of problem-solving can be effectively enhanced through inquiry activities combined with advance organizer.

This research is limited to the work and energy material of class $\mathrm{X}$ high school and could be more interesting suppose it is applied to other material in physics lessons or at different grade levels. The study is also limited to the effectiveness of the combined model in improving problem-solving skills. For this reason, further research should focus on the effectiveness of the model in improving contemporary skills such as communication, collaboration, critical thinking, innovation, and creativity.

\section{ACKNOWLEDGMENT}

The research team is profusely grateful to the Ministry of Research, Technology, and Higher Education for funding this research through a master's thesis research grant in 2019.

\section{REFERENCES}

Alfin, J., \& Fuad, A. (2019). Development of group science learning (GSL) model to improve the skills of collaborative problem solving, science process, and selfconfidence of primary schools teacher candidates. Int J of Instruction, 12(1), 147-164.

Amanah, P. D., Harjono, A., \& Gunada, I. W. (2017). Kemampuan Pemecahan Masalah Dalam Fisika Dengan Pembelajaran Generatif Berbantuan Scaffolding dan Advance Organizer. Jurnal Pendidikan Fisika dan Teknologi, 3(1), 84-91. 
Anderson, L., \& Krathwohl, D. A. (2001). A taxonomy for learning, teaching and assessing: A revision of bloom's taxonomy of educational objective. New York: Longman.

Andrini, V. S. (2016). The effectiveness of inquiry learning method to enhance students' learning outcome: A theoretical and empirical review. J of Edu and Prac, 7(3), 38-42.

Arslan, A. (2014). Transition between open and guided inquiry instruction. ProcediaSocial and Behavioral Sciences, 141, 407-412.

Artayasa, I. P., Susilo, H., Lestari, U., \& Indriwati, S. E. (2018). the effect of three levels of inquiry on the improvement of science concept understanding of elementary school teacher candidates. International Journal of Instruction, 11(2), 235-248.

Ausubel, D. P. (1968). Educational psychology: A cognitive view. New York: Holt, Rinehart and Winston.

Biljana, N. C., \& Dragana, S. (2017). Educational needs of teacher for introduction and application of innovative models in educational work to improve teaching. International Journal of Cognitive Research in Science, Engineering and Education, 5(1),49-56.

Budsankom, P., Sawangboon, T., \& Damrongpanit, S. (2015). Factors affecting higher order thinking skills of students: A meta-analytic structural equation modeling study. Educational Research and Review, 10(19), 2639-2652.

Bunterm, T., Wattanathorn, J., Vangppomyai, P., \& Muchimapura, S. (2012). Impact of open inquiry in science education on working memory, saliva cortisol and problem solving skill. Procedia-Social and Behavioral Sciences, 46, 5387-5391.

Creswell, J. W. (2012). Educational research: Planning, conducting, and evaluating quantitative and qualitative research. Boston, MA: Pearson Education Inc.

Datur, I. S., Yuliati, L., \& Mufti, N. (2016). Eksplorasi Kemampuan Pemecahan Masalah Siswa Fisika Pada Materi Fluida Statis. Prosiding Seminar Nasional Pendidikan IPA, 2, 294-300.

Docktor, J. L., Dornfeld, J., Frodermann, E., Heller, K., Hsu, L., Jackson, K. A., Mason, A., Qing, X. R., \& Yang, J. (2016). Assessing student written problem solutions: A problem-solving rubric with application to introductory physics. Physical Review Physics Education Research, 12(1), 0101301-01013018.

Gagne, R. M. (1980). Is educational technology in phase? Edu Technology, 20(2), 7-14.

Githua, B. N., \& Nyabwa, R. A. (2008). Effects of advance organizer strategy during instruction on secondary school students' mathematics achievement in Kenya's Nakuru district. International Journal of Science and Mathematics Education, 6(3), 439-457.

Gongden, E. J. (2016). The effects of analogy on male and female chemistry students' problem-solving ability in electrolysis. Int J of Scientific Research in Edu, 9(1), 1-6. 
Gunawan, G., Harjono, A., \& Sahidu, H. (2015). Pengembangan Model Laboratorium Virtual Berorientasi pada Kemampuan Pemecahan Masalah Bagi Calon Guru Fisika. Jurnal Materi dan Pembelajaran Fisika (JMPF), 5(2), 41-46.

Gunawan, G., Harjono, A., Hermansyah, H., \& Herayanti, L. (2019). Guided inquiry model through virtual laboratory to enhance students' science process skills on heat concept. Jurnal Cakrawala Pendidikan, 38(2), 259-268.

Gunawan, G., Harjono, A., Kusdiastuti, M., Nisyah M., \& Herayanti, L. (2019). Increasing students' critical thinking skills in physics using a guided inquiry model combined with an advanced organizer. J of Adv Res in Dyn \& Cont Sys, 11(7), 313-320.

Gunawan, G., Suranti, N. M. Y., Nisrina, N., \& Herayanti, L. (2018). Students' problem-solving skill in physics teaching with virtual labs. International Journal of Pedagogy and Teacher Education, 2, 79-90.

Hadi, S., Retnawati, H., Munadi, S., Apino, E., \& Wulandari, N. F. (2018). The difficulties of high school students in solving higher-order thinking skills problems. Problems of Education in the 21st Century, 76(4), 520-532.

Hake, R. (1999). Analyzing change/gain score. Indiana: Indiana University.

Hamdanillah, N., Harjono, A., \& Susilawati, S. (2017). Pengaruh Model Pembelajaran Advance Organizer Menggunakan Video Pembelajaran Terhadap Hasil Belajar Fisika Peserta Didik. Jurnal Pendidikan Fisika dan Teknologi, 3(2), 119-127.

Harjono, A. (2012). Perbedaan Strategi Pembelajaran dan Pemberian Advance Organizer Pengaruhnya Terhadap Hasil Belajar Fisika Siswa Kelas X. Jurnal Pijar MIPA, 7(1), 13-17.

Harjono, A., Gunada, I. W., Sutrio. S., \& Hikmawati, H. (2018). Penerapan Advance organizer dengan Model Pembelajaran Ekspositori Berpola Lesson Study Unruk Meningkatkan Hasil Belajar Fisika Peserta Didik. J Pendi Fisi dan Tek, 4(1), 141-150.

Heller, P., Keith, R., \& Anderson, S. (1992). Teaching problem solving through cooperative grouping. part 1: Group versus individual problem solving. American Journal of Physics, 60(7), 627-636.

Hermansyah, H., Gunawan, G., Harjono, A., \& Adawiyah, A. (2019). Guided inquiry model with virtual labs to improve students understanding on heat concept. Journal of Physics Conference Series, 1153(1), 012116.

Iofciu, F., Miron, C., \& Antohe, S. (2011). Graphic organizer for constructivist approach of advanced science concepts: "Magnetoresistance". Procedia Social and behavioral Sciences, 15, 148-152.

Joyce, B., Weil, M.., \& Alhoun, E. (2003). Model of teaching. Chicago: U Chicago.

Jua, S. K., Sarwanto., \& Sukarmin. (2018). The profile of students' problem-solving skill in physics across interest program in the secondary school. Journal of Physics Conference Series, 1022(1), 012027 
Jufri, A. W. (2017). Belajar dan Pembelajaran Sains. Bandung: Pustaka Reka Cipta.

Keselman, A. (2003). Supporting inquiry learning by promoting normative understanding of multivariable causality. J of Res in Science Teaching, 40, 898-921.

Kivunja, C. (2015). Exploring the pedagogical meaning and implications of the 4cs "super skills" for the 21st century through Bruner's 5e lenses of knowledge construction to improve pedagogies of the new learning paradigm. Creative Edu, 6(2), 224-239.

Korur, F., Toker, S., \& Eryılmaz, A. (2016). Effects of the integrated online advance organizer teaching materials on students' science achievement and attitude. Journal of Science Education and Technology, 25(4), 628-640.

Kostelníková, M., \& Ožvoldová, M. (2013). Inquiry in physics classes by means of remote experiments. Procedia-Social and Behavioral Sciences, 89, 133-138.

Mandani, S., \& Ochonogor, C. (2018). Comparative effect of two problem solving instructional strategies on students achievement in stoichiometry. Eurasia Journal of Mathematics, Science and Technology Education., 14(12), 1-9.

Mashami, R. A., \& Gunawan, G. (2018). The influence of sub-microscopic media animation on students' critical thinking skills based on gender. Journal of Physics: Conference Series, 1108(1), 012106.

Mayer, R. (2008). Learning and instruction. New Jersey: Pearson Education, Inc.

McManus, T. F. (2000). Individualizing instruction in a web-based hypermedia learning environment: Nonlinearity, advance organizers, and self-regulated learners. Journal of Interactive Learning Research, 11(2), 219-251.

Mefoh, P. C., Nwoke, M. B., Chukwuorji, J. C., \& Chijioke, A. O. (2017). Effect of cognitive style and gender on adolescents' problem solving ability. Thinking Skills and Creativity, 25, 47-52.

Naz, F., \& Murad, H. S. (2017). Innovative teaching has a positive impact on the performance of diverse students. SAGE Open, 7(4), 1-8.

OECD. (2016). PISA 2015 results: Excellence and equity in education (Vol. 1). OECD.

Raizen, S. A., \& Michelsohn, A. M. (1994). The future of science in elementary schools. Educating prospective teachers. San Francisco: Jossey-Bass.

Sari, N. M., Yaniawati, P. D., \& Kartasasmita, B. G. (2019). The effect of different ways in presenting teaching materials on students' mathematical problem solving skills. International Journal of Instruction, 12(4), 495-512.

Shihusa, H., \& Keraro, F. N. (2009). Using advance organizers to enhance students' motivation in learning biology. Eurasia J of Math, Sci \& Tech Edu, 5(4), 413-420.

Wahyuni, S., Kosim, K., Gunawan, G., \& Husein, S. (2019). Physics learning devices based on guided inquiry with experiment to improve students' creativity. Journal of Physics: Conference Series. 1233(1), 012034. 